\title{
COME ON MANN DON'T SEARCH ME! A CASE COMMENT ON R. V. C.J.F.
}

\author{
MiCHAEL A. JOHNSTON*
}

\section{INTRODUCTION}

In $M a n n^{1}$ the Supreme Court of Canada confirmed that the police have the power to detain individuals, albeit briefly, for investigative purposes. The Court also supplemented this power with the power to conduct protective searches incident to these investigative detentions (PSIIDs). While the Court made it clear that the power to conduct these searches was not incident to every investigative detention, ${ }^{2}$ this power should, nevertheless, be regarded dubiously. The conditions required to conduct a PSIID are lower than those required for a peace officer to make an arrest without a warrant under s. 495 of the Criminal Code $e^{3}$ for violations of ss. $88^{4}$ or $90^{5}$ of the Code. Allowing the police to wield both of these weapons against "crime” augments police power to engage in warrantless searches, and concomitantly decreases individual rights.

The recent decision of the Saskatchewan Provincial Court, Youth Justice Court, in C.J.F., ${ }^{6}$ illustrates the corrosive effect that Mann and its PSIIDs can have "on the right of individuals to walk the streets free from state interference." ${ }^{7}$ C.J.F. challenges us to ensure that Mann is being properly applied, but it also challenges us to understand the effect of having PSIIDs.

\section{THE FACTS OF C.J.F.}

On or about 13 September 2007, at 7:40 p.m. in North Battleford, two officers responded to a call and arrived at Sound City electronics store. They were investigating a report that four or five youths, one supposedly wearing a red cap, were "throwing something at the windows." 8 The officers saw a group of youths a block away, none of whom was wearing a red cap. The officers exited their vehicle and told the youths why they were in the area and asked if they knew anything about the incident at Sound City. C.J.F., one of the group

B.A.H., LL.B. The author would like to acknowledge the erudite contributions of Professor Glen E. Luther. Additionally, many thanks to Benjamin J. Kormos and Anna A. Singer.

R. v. Mann, 2004 SCC 52, [2004] 3 S.C.R. 59 [Mann].

Ibid. The Supreme Court grounded the power to conduct PSIIDs in the following way:

The general duty of officers to protect life may, in some circumstances, give rise to the power to conduct a pat-down search incident to an investigative detention. Such a search power does not exist as a matter of course; the officer must believe on reasonable grounds that his or her own safety, or the safety of others, is at risk. I disagree with the suggestion that the power to detain for investigative searches endorses an incidental search in all circumstances (at para. 40).

3 R.S.C. 1985 , c. C-46, s. 495 [Code]. Section 495(1) reads:

A peace officer may arrest without warrant (a) a person who has committed an indictable offence or who, on reasonable grounds, he believes has committed or is about to commit an indictable offence; (b) a person whom he finds committing a criminal offence; or (c) a person in respect of whom he has reasonable grounds to believe that a warrant of arrest or committal, in any form set out in Part XXVIII in relation thereto, is in force within the territorial jurisdiction in which the person is found.

Code, ibid., s. 88(1) prohibits the possession of a weapon for a dangerous purpose.

Code, ibid., s. 90(1) prohibits carrying a concealed weapon, a prohibited device, or prohibited ammunition, subject to being authorized by the Firearms Act, S.C. 1995, c. 39.

R. v. C.J.F., 2008 SKPC 51, 315 Sask. R. 190 [C.J.F.].

Mann, supra note 1 at para. 1 .

C.J.F., supra note 6 at para. 5. 
members, began to walk away. Constable Hill called three times for him to return. C.J.F. walked for about 20 metres and then began to run away. Constable Hill chased after him, and when C.J.F. stopped running, he was handcuffed and placed under arrest for obstruction; he was subsequently patted down. The search revealed a collapsible defence baton in C.J.F.'s front right pocket. ${ }^{9}$ C.J.F. was charged with violating ss. 88 and 90 of the Code.

At trial, Constable Hill testified that he pursued C.J.F. because his experience had taught him that people in North Battleford run from the police when there is a warrant out for their arrest, they are on conditions, they are hiding something, or they are connected to the matter being investigated. ${ }^{10}$ The search that ensued was, according to Constable Hill, conducted for "officer safety reasons." ${ }^{11}$ He was unsure why C.J.F. had stopped running and he wanted to ensure that he did not possess any weapons, or "whatever hard objects were being thrown at the windows." 12

\section{THE DECISION OF THE COURT IN C.J.F.}

The two central issues addressed in this case were:

(1) Whether the detention of C.J.F. was lawful (the Crown conceded that his arrest was unlawful); and

(2) Whether the search was justified and reasonably necessary. ${ }^{13}$

The Court's analysis began by stating that the police have the common law authority to detain individuals if the detention is reasonably necessary and is conducted in a reasonable manner. Additionally, the police can search those individuals if the circumstances create reasonable necessity and the search is conducted reasonably. ${ }^{14}$ Parts of the Mann decision were then cited to support the Court's propositions. ${ }^{15}$ Next, attention shifted to the application of Mann in Clayton. ${ }^{16}$ The Court drew a comparison between C.J.F. and Troy Farmer in Clayton, ${ }^{17}$ who was also unlawfully arrested, but whose detention and search was ultimately found not to violate ss. 8 and 9 of the Canadian Charter of Rights and Freedoms. ${ }^{18}$

Based upon the surrounding circumstances, and the jurisprudence, the Court held that there were reasonable grounds for Constable Hill to both detain and search C.J.F. He had been among a group of youths in close proximity to the area described in the complaint and he had fled when he was questioned. Once Constable Hill caught C.J.F., he had grounds to continue to detain C.J.F., to handcuff him, and to search him for safety reasons. ${ }^{19}$ When a

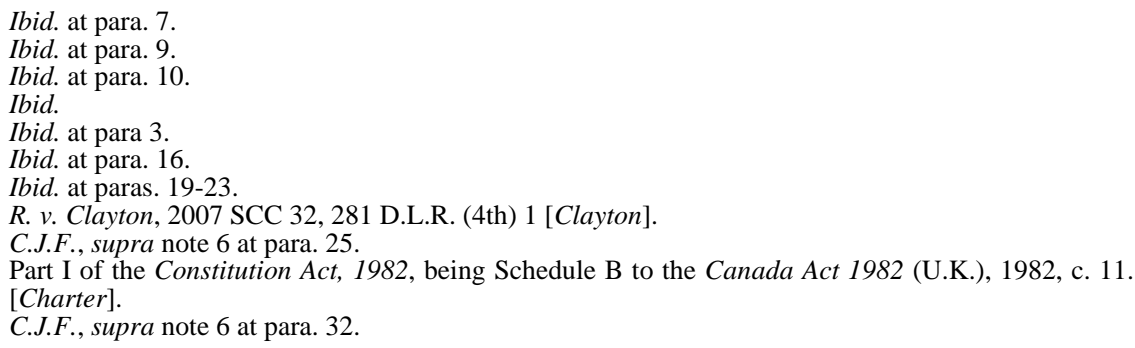


hard object was detected in his pocket, there were grounds to continue the search and seize the weapon. There was also some urgency attributed to the situation because Constable Hill had left his rookie partner behind with the other youths. The words of arrest were found to have had no impact on the lawfulness of the detention or the lawfulness of the search. ${ }^{20}$ Accordingly, the Court was satisfied that the Crown had proven, on a balance of probabilities, that the search was lawful and that it was carried out in a reasonable manner. ${ }^{21}$ Therefore, C.J.F.'s rights under ss. 8 and 9 of the Charter were not violated and he was convicted on both counts. ${ }^{22}$ In order to understand the errors in C.J.F., and the impact that PSIIDs can have on the legal system, it is worth returning to the precursor of this police power - Mann.

\section{R. V. MANN AND THE LEGALIZATION OF THE PSIID}

In a broad sense, Mann was about finding the right balance between civil liberties and law and order. The Court had to consider whether or not there was a common law power to detain individuals briefly for investigative purposes and, if there was such a power, whether or not it included the power to conduct some sort of search. Their decision, while intending to create clarity, succeeded in greater obscurity. ${ }^{23}$ This obscurity has not been elucidated in favorem vitae.

Building upon the Waterfield test ${ }^{24}$ and upon the Ontario Court of Appeal's decade old decision in Simpson, ${ }^{25}$ the Court held that, in order for the police to detain individuals for investigative purposes, police need to have "reasonable grounds" to detain. ${ }^{26}$ The term "reasonable grounds" was a substitution for the term "articulable cause,” but it still required that there be objective and subjective reasons for the detention. ${ }^{27}$ This requirement means that a detention must be reasonably necessary when the totality of the circumstances is viewed objectively. The "officer's reasonable suspicion that the particular individual is implicated in the criminal activity under investigation" ${ }^{28}$ should inform the objective component. The decision to detain, and its "reasonableness," is further assessed, taking into account the right interfered with, the extent of the interference, and the need for the interference in order for the police officer to fulfill their duty. ${ }^{29}$ The detention should be brief in nature and there is no obligation for a detainee to answer questions. These powers are apparently not to be confused with the power to arrest and search incidentally. ${ }^{30}$ Additionally, the Court stated that a detainee is entitled to be informed of the reason for their detention in conformity with s. 10(a) of the Charter. ${ }^{31}$ However, the Court was not as conclusive about a detainee's s. 10(b) Charter rights; they believed that demanding rigid compliance with s. 10(b) could

Ibid. at para. 35 .

Ibid. at para. 34 .

Ibid. at paras. 37-38. With regards to carrying the weapon for purposes dangerous to the public peace, the Court summarily rejected C.J.F.'s reason for having the baton.

James Stribopoulos, "The Limits of Judicially Created Police Powers: Investigative Detention After Mann” (2007) 52 Crim L.Q. 299 at 301.

R. v. Waterfield (1963), [1964] 1 Q.B. 164 at 170-71 [Waterfield].

R. v. Simpson (1993), 12 O.R. (3d) 182 (C.A.) [Simpson].

Mann, supra note 1 at para. 34.

Ibid. at para. 27.

Ibid. at para. 34 .

Ibid.

Ibid. at para. 45.

Ibid. at para. 21. 
prolong a detention whose hallmark was supposed to be brevity. ${ }^{32}$ Ultimately, the Court left the determination of a detainee's s. 10(b) rights for another day. ${ }^{33}$

The Court then returned to the Waterfield test to establish the power to conduct PSIIDs. The power to conduct PSIIDs stems from an officer's duty to protect life, and it may be conducted in circumstances in which an officer has reasonable grounds to believe that his or her safety, or the public's safety, is in danger. ${ }^{34}$ The reasonableness of the search will be assessed against the "totality of the circumstances" and it will not be justified on mere hunches. ${ }^{35}$ Furthermore, as with any search, it must also be authorized by a reasonable law and must be carried out in a reasonable manner.

\section{The EFFEcts of HaVINg PSIIDs}

Everyone may not agree with the Supreme Court of Canada's decision in Mann confirming police power for investigative detentions and PSIIDs, but these powers are here to stay. Even before the Mann decision, there was fear that Simpson would be expanded in ways that would adversely affect civil liberties. For example, Professor Tim Quigley believed that the most troubling part of Simpson was the searches that might accompany investigative detentions. ${ }^{36}$ Parliament had already failed to regulate the power to search incident to an arrest, preferring to entrust the courts with this task. ${ }^{37}$ In spite of this failure, searches incident to an arrest could be viewed as having some implicit regulation, given the reasonable and probable grounds needed for the arrest itself. In Caslake, ${ }^{38}$ the Court stated that the power to search incident to arrest "is justifiable because the arrest itself requires reasonable and probable grounds (under s. 494 of the Code) or an arrest warrant (under s. 495). However, since the legality of the search is derived from the legality of arrest, if the arrest is later found to be invalid, the search will be also."39 Professor Quigley feared the reduced basis upon which PSIIDs, which were, as such, warrantless searches, might be allowed. This concern was not unfounded. The police now have two kicks at the proverbial can: if an arrest and its incidental search are found to be illegal, it may still be salvaged if the lesser standards for an investigative detention and PSIID are satisfied. This does not bode well for the privacy interests of the individual.

Hunter $^{40}$ remains the authoritative declaration on the constitutional protection of privacy. Dickson J. (as he then was) wrote:

The state's interest in detecting and preventing crime begins to prevail over the individual's interest in being left alone at the point where credibly-based probability replaces suspicion. History has confirmed the

Ibid. at para. 22 .

Ibid.

Ibid. at para. 40

Ibid.

Tim Quigley, “Brief Investigatory Detentions: A Critique of R. v. Simpson” (2004) 41 Alta. L. Rev. 935 at 944 .

Ibid. at 945 .

R. v. Caslake, [1998] 1 S.C.R. 51 [Caslake].

Ibid. at para. 13.

Hunter v. Southam Inc., [1984] 2 S.C.R. 145 [Hunter]. 
appropriateness of this requirement as the threshold for subordinating the expectation of privacy to the needs of law enforcement. ${ }^{41}$

This passage is important because it explicitly states that it is probability, not suspicion, that must justify the state's actions when individual privacy interests are subsumed. To refer back to Mann, the Court stated the following:

[P]olice officers may detain an individual for investigative purposes if there are reasonable grounds to suspect in all the circumstances that the individual is connected to a particular crime and that such a detention is necessary. In addition, where a police officer has reasonable grounds to believe that his or her safety or that of others is at risk, the officer may engage in a protective pat-down search of the detained individual. ${ }^{42}$

A plain reading of this passage suggests that the criteria needed to engage in a PSIID is higher than that needed for an investigative detention, but lower than what is required to make an arrest. Succinctly, the standard needed for PSIIDs lurks somewhere between these two poles. This allows for the state's interest to prevail over those of the individual, based upon something that may only be slightly greater than a credibly-based suspicion. The regulation of these searches, like searches incident to an arrest, have been entrusted to the judicial plume, rather than the legislative mace. The problem with this, as Professor James Stribopoulus has stated, is that the regulation of these types of powers is too elaborate for judicial elucidation. Questions regarding the amount of force that may be used to exercise PSIIDs, whether or not a detainee be moved, and the content of a detainee's s. 10(b) rights are important issues that will only be resolved in the wake of Mann. ${ }^{43}$ These lacunae arguably violate the requirement that laws "provide sufficiently clear standards to avoid arbitrary and discriminatory applications by those charged with enforcement." ${ }^{44}$ In fact, the Court seems to have been blind to the adverse impact that these new powers might have on visible minorities. $^{45}$

One of the challenges involved in regulating PSIIDs is the ambiguity of the term "reasonable and probable grounds." The use of this language appears to engage the standard needed for a conventional arrest, which is perplexing. ${ }^{46}$ It is baffling because the language used to communicate the standards needed for a conventional arrest has its own shortcomings. As pointed out by LaForest J., in his dissent in Landry: ${ }^{47}$

Let me first say something about the vagueness of the proposed test of "reasonable and probable cause" and the consequential danger of giving the police power to enter into a private dwelling on that basis. The expression, no doubt, comprises something more than mere surmise, but determining with any useful measure of precision what it means beyond that poses rather intractable problems both for the police and the courts. ${ }^{48}$

Ibid. at 167-68.

Mann, supra note 1 at para. 45.

Stribopoulos, supra note 23 at 308-309.

Peter W. Hogg, Constitutional Law of Canada, Student Edition 2007 (Scarborough: Thomson Canada, 2007) at para. 38.7(c).

Stribopoulos, supra note 23 at 304.

Ibid. at 311.

R. v. Landry, [1986] 1 S.C.R. 145 [Landry].

Ibid. at 180 . 
Deciphering the content of the concept "reasonable and probable," in the context of an arrest, may be difficult. Having a secondary power with a lower standard that affords the police the power to stop, and in some cases search, individuals eases the problem by giving the police and the courts greater latitude to validate their actions subsequently. ${ }^{49}$ This means that: (i) the Waterfield test has diluted the privacy interests envisioned in Hunter; (ii) the reasonable grounds needed for PSIIDs may be no more than a glorified suspicion; and (iii) the grounds upon which warrantless searches can be permitted are slight.

\section{THE Misapplication OF MANN IN C.J.F.}

In C.J.F., the two officers were looking for four or five kids, one of whom was wearing a red cap. They found a group of kids a block away (the judgment is silent on the exact number), none of whom was wearing a red cap. When the police questioned the group, C.J.F. fled. The learned trial judge found that, because C.J.F. was in the immediate vicinity of the reported mischief, and because he fled, Constable Hill had reasonable grounds to suspect him. In this case, Constable Hill stated that he chased after C.J.F. because he felt that he may be hiding something from him and that he "may have been involved in the mischief complaint." 50 The major cause for his suspicion was that C.J.F. ran from the police. It is important to note that at no time did the officers tell the group of kids that they were being detained for investigative purposes. If the kids in the group were detained for investigative purposes, but were also not advised of the reason for their detention as required by s. 10(a) of the Charter and Mann, then how would they know that walking or running away would be of consequence? The learned trial judge erred by making no reference to the breach of s. 10(a) of the Charter in her decision.

Another aspect of Mann that is not addressed in C.J.F. is the fact that an individual is not obligated to respond to police questioning if there is an investigative detention. What is unclear about Mann is how the power to briefly detain individuals for investigative purposes is of any use if individuals are not obligated to respond to questions? The Court's failure in Mann to decide the matter of a detainee's s. 10(b) Charter rights currently makes a detainee's right to not respond to questions somewhat meaningless, and simultaneously makes the

Another post-Mann case from Saskatchewan that illustrates a problem with PSIIDs is R. v. Nguyen, 2004 SKQB 428, 256 Sask. R. 4 [Nguyen]. In Nguyen, a police officer detained a van that he suspected because it had been speeding (it was doing $109 \mathrm{~km} / \mathrm{h}$ on a $100 \mathrm{~km} / \mathrm{h}$ highway) and, upon seeing the police cruiser, had slowed down. During the detention, the officer apparently detected a faint smell of marijuana and subsequently discovered that both passengers were facing charges under the Controlled Drug and Substances Act, S.C. 1996, c. 19 and the Code. The officer detected a very faint smell of fresh cannabis a second time and, as a result, detained both passengers. The officer said he did not arrest the individuals at that point because he believed that he did not have reasonable and probable grounds for an arrest. He did conduct a PSIID of both men. Additionally, he conducted a search of the vehicle, which could not have been for officer safety reasons as both men had been placed in the back of the police cruiser and thus is completely inconsistent with the reason for having PSIIDs. The search of the van led to the discovery of a non-factory compartment he believed, based on his prior experience, was being used to carry drugs. He also saw the corner of a plastic bag sticking out from said compartment. As a result, he arrested both men. Once back at the station, the officer used the information obtained from his roadside search to procure a search warrant, which led to the discovery of 57 pounds of marijuana. The Court held that the detention was not arbitrary as there were reasonable grounds to suspect that the accused was connected to the offence of possession of marijuana. However, the roadside search was deemed to be unreasonable. That being the case, the search warrant that was obtained based on information emanating from the roadside search was invalid. Notwithstanding this determination, the evidence was admitted. Among other things, the Court stated that the officer had been acting in good faith, honestly believing that he had a right to conduct a PSIID of the vehicle. 
investigative detention potentially fruitful. However, C.J.F. seems to stand for the proposition that silence or non-compliance can be used against you, as C.J.F's noncompliance (running away) was used to substantiate the officer's reasonable ground to suspect him. ${ }^{51}$ It was C.J.F.'s right to not answer any questions and to leave at any time. Exercising his rights should not have been used to his detriment.

Professor Quigley, almost clairvoyantly, stated:

Citizens are generally not knowledgeable about their own rights or about the scope of police powers. As a consequence, it should be no surprise that some suspects will flee or resist when faced with an investigative detention. It is disturbing, then, for the courts to uphold force as an adjunct to brief investigatory detentions, for along with that additional power will undoubtedly come more police-generated offences, such as obstruction, resisting arrest, or assaulting a peace officer. ${ }^{52}$

When C.J.F. was caught, he was arrested for obstruction. The learned trial judge stated that at that point, Constable Hill had reasonable grounds to further detain C.J.F., handcuff him, and conduct a protective pat-down search. ${ }^{53}$ Nowhere in Mann will you find anything that suggests that handcuffs are part of the investigative detention or PSIID. Being placed in handcuffs seems to not only ignore the "brief in duration" criteria, ${ }^{54}$ but it also simultaneously raises the "reasonableness" threshold as C.J.F's rights were more seriously infringed. Part of that "reasonableness" threshold looks at the need for the interference in order for a police officer to fulfill their duty. The necessity of an officer to chase down a young man and place him in handcuffs in order to ask him a question that he does not need to respond to, simply because he was in the area of the reported mischief, is not apparent.

What also needs to be questioned about the learned trial judge's reasoning is her finding that Constable Hill was justified in conducting a pat-down search subsequent to C.J.F. being placed in handcuffs. Once C.J.F. was in handcuffs, what safety issues could he pose to the police officer or to the public? The learned trial judge states that Constable Hill did not know why C.J.F. ran away and that he did not know what objects C.J.F. might have on his person. This was used to fulfill the reasonable grounds requirement needed for a PSIID. ${ }^{55}$ The fact that someone runs away from the police, coupled with an officer being unsure about what a suspect has on their person, should hardly be grounds for allowing a warrantless search, even if it is simply a pat-down. People can run away from the police for a variety of reasons, and since police officers are not prescient, they will never have knowledge of what is on someone's person. Allowing a search on these grounds should have us all worried.

In this case, reasonable grounds seems to have been met because a police officer felt something based on his experience. ${ }^{56}$ Is a feeling not analogous to a hunch or mere intuition? "Courts have a duty to stop this type of crime-control popularization and fantasy, which allows for officers' 'general suspicions' to dictate their actions." 57 Furthermore, Mann said

Ibid. at para. 31.

Quigley, supra note 36 at 944.

C.J.F., supra note 6 at para. 32.

Mann, supra note 1 at para. 45.

C.J.F., supra note 6 at para. 32 .

Ibid. at para. 9.

Christina Skibinsky, “Regulating Mann in Canada” (2006) 69 Sask. L. Rev. 197 at 207. 
investigative detentions should be distinguished from de facto arrests, although is that not, in essence, what occurred in C.J.F. ${ }^{58}$ As stated in Caslake, if an arrest is illegal the incidental search should also be declared illegal. One difference between an arrest and its incidental search and an investigative detention and a PSIID is that the PSIID has its own requirements that must be satisfied. Nonetheless, if the investigative detention ends up being illegal and the same grounds are used to justify a PSIID, then it seems logical to conclude that the search should also be deemed illegal. Unfortunately, this was not the case in C.J.F.; not only were the grounds for his detention specious, but they were recycled and repackaged as the grounds for the PSIID, and they were accepted as valid for both.

\section{Conclusion}

C.J.F.'s arrest and his ultimate conviction are contrary to what the Supreme Court had envisioned in Mann. Even if Mann is applied properly, the fact that the police have this new power to conduct warrantless searches should be sharply questioned. In terms of protecting officer and public safety, s. 495 of the Code should be sufficient to allow an officer to arrest a person for actions contrary to ss. 88 or 90 of the Code. This is especially true when one considers the definition of "weapons" under s. 2 of the Code, ${ }^{59}$ the propensity of the courts to find in favour of the police when they are acting in "good faith," and the malleability of the concept of "reasonable and probable" grounds. The police should not have two opportunities to get a warrantless search right. Their one attempt should have, as its minimum requirement, a credibly-based probability, not a glorified suspicion, or some vague ether in between.

It is in this ethereal realm where the courts have demonstrated that they are not sure how to apply Mann. The cost of fighting crime through the use of investigatory detentions, PSIIDs, and a liberal interpretation of Mann is high: freedom. ${ }^{60}$ Francisco de Paula Santander, a Colombian Revolutionary and Politician, stated that through the use of weapons, his country had gained independence from Spain, but it was the laws that would make them free. ${ }^{61}$ When laws serve to unpredictably and unnecessarily curtail freedom, at the very least, pens must be unsheathed.

$59 \quad$ Code, supra note 3, s. 2, defines a weapon as: "any thing used, designed to be used or intended for use (a) in causing death or injury to any person, or (b) for the purpose of threatening or intimidating any person and, without restricting the generality of the foregoing, includes a firearm."

60 Skibinsky, supra note 57 at 199.

61 See Michael Reid, Forgotten Continent: The Battle for Latin America's Soul (New Haven: Yale University Press, 2007) at 52. 